\title{
Psychological Contract, Reciprocal Preference and Knowledge Sharing Willingness
}

\author{
Liangtie Dai, Lei Wang \\ School of Management, Jinan University, Guangzhou, China \\ Email: 827444677@qq.com
}

Received 18 July 2016; accepted 19 August 2016; published 22 August 2016

Copyright (C) 2016 by authors and Scientific Research Publishing Inc.

This work is licensed under the Creative Commons Attribution International License (CC BY). http://creativecommons.org/licenses/by/4.0/

(c) (i) Open Access

\begin{abstract}
The paper has undertaken field investigation on 370 knowledge workers in knowledge-based industries which are located in Pearl River Delta region by structured questionnaire, and verifies that the different influence of psychological contract and reciprocal preference on knowledge sharing willingness, and further confirms that the reciprocal preference plays an intermediary in the relationship between psychological contract and knowledge sharing willingness. The result of analysis shows that: 1) Transactional psychological contract has a negative effect on knowledge sharing; 2) Relational psychological contract has a significant positive effect on knowledge sharing; 3) Developmental psychological contract only has a significant negative effect on the explicit knowledge sharing; 4) The reciprocal preference plays an intermediary role in the relationship between transactional psychological contract, relational psychological contract.
\end{abstract}

\section{Keywords}

\section{Psychological Contract, Reciprocal Preference, Knowledge Sharing Willingness}

\section{Introduction}

In the era of knowledge economy, knowledge has been regarded as the most important competitive resource of the organization, and the effective knowledge management has become one of the main ways to obtain the competitive advantage. However, the advantage of knowledge, which must be grasped by the person and share with each other can play and then can be transformed into innovative behavior and innovative products. One study found that knowledge sharing helps to reduce production costs, accelerate new product development speed, improve team performance and the performance of the company [1]. British scholar Polanyi was the first person 
who divided the knowledge into the explicit knowledge and tacit knowledge. Explicit knowledge is easy to code, express and transmit, and the tacit knowledge is the one that we understand but it is difficult to spread openly or that can't be expressed with any choice of words. Cohen and Levinthal's [2] study found that the hidden knowledge that existed within the individual was more capable of improving the organization's innovation behavior than the explicit knowledge. Obviously encouraging employees to share their knowledge, especially the tacit knowledge, is an important guarantee for the long-term development of the organization. Although the present information technology is highly developed and most of the enterprises have established their own knowledge management system, and the information exchange among employees becomes more convenient, most organizations find it a great obstacle to share their own knowledge, especially tacit knowledge, in order to make employees take the initiative to share their own knowledge [3]. An important reason for the failure of knowledge management system to promote knowledge sharing is not to take into account the organizational context and individual factors of employees, and most business managers also think that the biggest obstacle of implementing knowledge management system lies with the individual itself, such as the lack of material incentives, and there is no time to talk, no training, and not in the lack of the support of information technology. Husted and Michailova et al. [4] thought that the staff who had the unique tacit knowledge often connected it with the performance appraisal, staffing, personal income, promotion, flexible work distribution problem of interest contact together, which for knowledge sharing formed a hindrance. Because they share their tacit knowledge with others, the final result will be lost in a knowledge or technology advantage, and there is no corresponding material incentive or rewards. The individual is very difficult to take the initiative to carry out knowledge sharing. So it is very important to explore the influencing factors of knowledge sharing. Previous studies mostly focused on the impact of economic factors on knowledge sharing, but the factors of the individual itself mostly remain in the theory. So this paper will systematically study the mechanism of the impact of psychological contract on knowledge sharing willingness, and meanwhile introduce the reciprocal preference as a mediator to explore the internal relations between the psychological contract, reciprocal preference and knowledge sharing willingness.

\section{Literature Review}

\subsection{Psychological Contract and Its Structure}

The concept of psychological contract can be traced back to the understanding of organizational behavior written by Argyris [5], with the "psychological contract" to understand the hidden and informal relations between workers and leaders. Levinson defined psychological contract as relations between the two sides who may not aware of, but a series of expectations that control the relationship between the two parties, and pointed out that such mutual expectations was recessive in the book the people, management, mental health. Kotter [6] believed that psychological contract was the hidden contract between individuals and organizations, each party was eager to get some kind of reward or benefit from the opposite side. American scholar Rousseau [7] made a further detailed explanation of psychological contract, and defined it as an individual's understanding and belief in the mutual obligations of the employer based on the commitment, trust and perception in the context of the employment relationship.

Currently the structure theory of psychological contract mainly has two-dimensional structure and three dimensional structure. Two-dimensional structure theory was proposed by Neil Mac which divided psychological contract into two dimensions: transactional and relational; And Rousseau and Tijorimala further pointed out the three dimensional structure of the psychological contract, namely the transactional dimension, the relational dimension and team member dimension. Transactional dimension refers to the organization provide employees with economic and material benefits, correspondingly, the staff also need to assume the corresponding task; relational dimension refers to both the employees and organizations focus on the future, long-term and stable relationship, as a result promote the development of both sides; team member dimension refers to the employees and organizations are concerned about interpersonal support and good interpersonal relationship. Rousseau [8] divided the psychological contract into 4 types: transactional, relational, balanced and variable, from the angle of contract period between employees and employers long-term or short-term, as well as the performance requirements are clearly defined or not. $\mathrm{Li}$ [9] found that the three-dimensional structure was more reasonable than the two-dimensional for the Chinese employees through the investigation of 796 subjects, namely normative responsibility, interpersonal responsibility and developmental responsibility, and the developmental psychological contract refers to employees are more concerned about the company's prospects of career, the value of work, 
salary, benefits and so on. At present, most scholars support the three-dimensional structure model and this paper will divide it into transactional dimension, relational dimension, developmental dimension base on the study of the three-dimensional model of psychological contract which from Rousseau and Li.

\subsection{Reciprocal Preference}

The research of reciprocal preference originated from the field of biology and later it was further developed in the fields of psychology, anthropology, behavioral economics and so on. Trivers Robbert, a biologist, first explained the reciprocal altruism and Matthewz Rabin, an economist, introduced the reciprocal preference into the field of economics, breaking the monopoly position of the rational economic man of the new classical economics; Rabin [10] thought that reciprocal preference was "if someone is good to you, then you also want to be good to him; if someone is not friendly to you, then you will not be friendly to him"; at the same time, people would sacrifice their own benefits to help those who are friendly to them or sacrifice benefits to punish those who are not friendly to them. An important feature of the reciprocal psychology is that perceiving others' behavioral motivation, willingness is the basis of behavioral responses he made and what decides the attitude and behavior towards others is decided by the motivation rather than the behavior itself. When people get help from others, they tend to make a distinction between what is active and what is forced to do. Goranson and Berkowitz [11] proved this point through the experiment of volunteered to help, it found that compared to those who were forced to provide help to people, subjects were more likely to return those who were willing to provide help. Reciprocal preference includes two aspects of reciprocity and mutual benefit, and the reciprocal motivation leads to reciprocal behavior. The reciprocal motivation is the motivation of the employees to repay the kindness of others and to retaliate against the hostile behavior of others. The behavior that is produced by the reciprocal motivation is the reciprocal behavior, among which the reward for the good behavior of others is called positive reciprocity.

\subsection{Knowledge Sharing Willingness}

British scholar, Poland, firstly divided the knowledge into explicit knowledge and tacit knowledge and Sternberg [12] thought tacit knowledge could be divided into technical and cognitive, made by the mental models, values, beliefs, insight and other components. Liebowitz and Beckman believed that tacit knowledge was automatically encoded and required little or no time to think so that it can help organizations to make decisions quickly and even affect the behavior of the collective. Now knowledge has been regarded as the most important strategic resources in the organization, and the effective management of knowledge, especially tacit knowledge management, has become the key to the success of enterprises; many studies also show that the transformation and sharing of tacit knowledge will bring more innovative behavior and knowledge creation. Cohen and Levinthal found that tacit knowledge which exists in the individual than explicit knowledge can improve the organization's innovation. Kang and Kim [13] defined knowledge sharing as knowledge flow from the person who owns it to the person who needs it; Dyer and Nobeoka [14] believed that knowledge sharing was to promote the exchange of knowledge between each other, to guide a correct learning direction, and to improve the ability to achieve personal and organizational goals; Storey [15] thought that knowledge sharing was a process of exchanging thoughts of each other or sharing common goals and similar problems; Vanden and Ridder further explained that knowledge sharing is a process of exchanging knowledge and creating new knowledge together.

\section{Hypothesis and Model}

\subsection{The Influence of Employee Psychological Contract on Knowledge Sharing Willingness}

Psychological contract is a psychological bond to maintain the relationship between employees and organizations, meanwhile the type and state of psychological contract also influence the behavior and attitude of the employees to the organization and others. Psychological contract is the basis of trust in the employment relationship. When employees trust the organization, they will make more contributions to the organization to get more returns. Reciprocal theory thinks that when you become a beneficiary, it will produce a sense of obligation to repay, a kind of psychological pressure, such a kind of psychological cognitive style generally exists in the social culture system. Psychological contract is an implicit contract, a mutually obligation between person and organization, when their needs (material, and inter organizational relationship, interpersonal relation) meet, their altruistic behavior rewarded, the person will be more likely to make Pro organizational behavior, but also to 
share their knowledge. Atkinson believed that employees' perception of psychological contract relationship will affect their attitude and behavior towards organization in the future, including knowledge sharing. Previous studies have confirmed that there was a certain relationship between psychological contract and knowledge sharing: Hislop [16] found that employee's psychological contract affected their attitude of the knowledge sharing, the contract restraint originating from the different levels of organization will affect their attitude and behavior of knowledge management, and further influence the knowledge sharing; Liang and Yu [17] found that the transformation and sharing of tacit knowledge was closely related to the psychological contract; He and Li's [18] empirical studies have found that different psychological contract types have different effects on the tacit knowledge sharing willingness for the knowledge intensive enterprise employees; Lu and Chen [19] found that the relational psychological contract had a significant positive impact on both explicit and tacit knowledge in the high tech enterprise, which is the key factor of knowledge sharing. Based on the above sharing, this paper puts forward the following assumptions:

H1: Psychological contract has a significant impact on the knowledge sharing willingness.

H1a: Transactional psychological contract has a significant negative impact on explicit knowledge sharing willingness.

H1b: Transactional psychological contract has a significant negative impact on tacit knowledge sharing willingness.

H1c: Relational psychological contract has a significant positive impact on explicit knowledge sharing willingness.

H1d: Relational psychological contract has a significant positive impact on tacit knowledge sharing willingness.

H1e: Developmental psychological contract has a significant positive impact on explicit knowledge sharing willingness.

H1f: Developmental psychological contract has a significant positive impact on tacit knowledge sharing willingness.

\subsection{The Influence of Employees' Reciprocal Preference on Knowledge Sharing Willingness}

According to the social exchange theory, whether an individual is involved in an exchange is considered from two aspects of cost and expected profit. When the income is greater than the cost, the individual will take an active part in the exchange behavior; if the expectation of reward or benefit is greater, the employee will be more inclined to share his knowledge; while the reciprocity preferences can create an atmosphere of trust between the members of an organization, and employees are willing to share their knowledge, because they are convinced that in the future the knowledge receiver can provide help, cooperation and support for them; reciprocal behavior can provide a sense of mutual indebtedness, resulting in knowledge contributors expect o to get help from others in order to ensure continued support for knowledge sharing [20]; G.W Bock's [21] studies have found that reciprocal benefits could provide an effective motivation to promote knowledge sharing in order to achieve long-term cooperation. Goh See-Kwong and Sandhu Manjit-Singh's [22] study confirmed that highly mutually beneficial employees tended to share their knowledge and experience; Zhang and Pu's [23] study confirmed that the reciprocal management strategy could promote the realization of the transformation of tacit knowledge and thus greatly improved the enterprise's ability of technological innovation. So if employees believe that they can get the mutual benefit from other colleagues by sharing their knowledge, they are more likely to believe that knowledge sharing is value, thus having higher knowledge sharing willingness. Based on the above analysis, this paper puts forward the following assumptions:

H2: Reciprocal preference has a significant positive effect on knowledge sharing willingness.

$\mathrm{H} 2 \mathrm{a}$ : Reciprocal motivation has a significant positive effect on the reciprocal behavior.

$\mathrm{H} 2 \mathrm{~b}$ : Reciprocal behavior has a significant positive impact on explicit knowledge sharing willingness.

$\mathrm{H} 2 \mathrm{c}$ : Reciprocal behavior has a significant positive impact on tacit knowledge sharing willingness.

\subsection{Reciprocal Preference Plays a Mediation Role in the Relationship between Psychological Contract and Knowledge Sharing Willingness}

The longitudinal study of Cooman [24] confirmed that the employee's psychological contract is a kind of reci- 
procal relationship with the attitude towards the organization and different psychological contract will affect the relationship of reciprocity, and then affect the attitude towards the organization. From the perspective of psychological contract, transactional psychological contract is a relationship to pursue short-term interests for the hired two sides, having this type of contract employees tend to consider their own interests met or not, very little to care about others interests of gains and losses, which also makes them of reciprocal preference may greatly reduce. The relational psychological contract focuses on the long-term stable relationship beyond the economic interests, and in order to achieve a win-win situation and the pursuit of a harmonious relationship, individual will produce some reciprocal motivation and behavior. Employees who are developmental psychological contract pursue the career success, self -realization, from another point of view, by sharing the knowledge with others can also bring benefit for their careers and their reciprocal preferences also will become more and more. Reciprocity can make form a long-term and stable relationship between employers and employees so that employees can work in a relaxed, pleasant conditions, and through mutual help from each other, employees can get more sense of security and a sense of trust, knowledge sharing's, especially tacit knowledge sharing, obstacles will be greatly reduced. When the enterprises and organizations meet employee's needs or give them some reward, from the perspective of reciprocity, employees will devote all their efforts to the development of organization, intentionally or unintentionally, their own interests with the enterprise development, the result is to link their own interests to the development of the enterprise consciously or unconsciously, forming a virtuous circle. Based on the above analysis, we put forward the following assumptions:

H3: Reciprocal preference plays a mediation role in the relationship between psychological contract and knowledge sharing willingness.

H3a: Reciprocal preference plays a mediation role in the relationship between transactional psychological contract and explicit knowledge sharing willingness.

$\mathrm{H} 3 \mathrm{~b}$ : Reciprocal preference plays a mediation role in the relationship between relational psychological contract and explicit knowledge sharing willingness.

H3c: Reciprocal preference plays a mediation role in the relationship between developmental psychological contract and explicit knowledge sharing willingness.

H3d: Reciprocal preference plays a mediation role in the relationship between transactional psychological contract and tacit knowledge sharing willingness.

$\mathrm{H} 3 \mathrm{e}$ : Reciprocal preference plays a mediation role in the relationship between relational psychological contract and tacit knowledge sharing willingness.

H3f: Reciprocal preference plays a mediation role in the relationship between developmental psychological contract and tacit knowledge sharing willingness.

Based on the above assumptions, the expected model diagram is obtained, as shown in Figure 1.

\section{Research Method}

\subsection{Research Sample}

In this study, a total of 400 questionnaires were distributed in the field and e-mail, the actual recovery of 375 copies, 370 valid questionnaires, the effective recovery of the questionnaire was $92.5 \%$. And the exclusion criterion is that more than $10 \%$ of the items were not answered or the items were obviously disorderly answered.

The basic characteristics of the sample are described in Table 1.

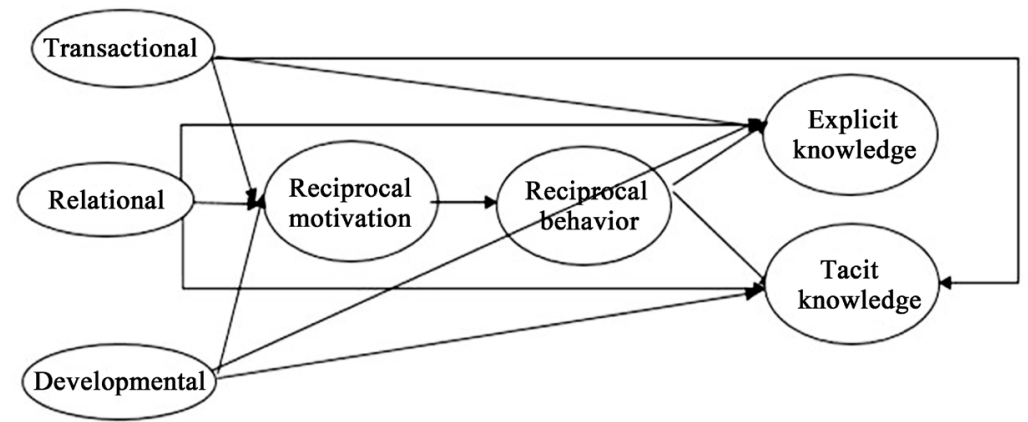

Figure 1. The expected model. 
Table 1. Descriptive statistics of the basic features of samples.

\begin{tabular}{cccc}
\hline Variable & Category & Number & Percentage \\
\hline \multirow{2}{*}{ Sex } & Male & 232 & $62.70 \%$ \\
& Female & 138 & $37.30 \%$ \\
\hline \multirow{2}{*}{ Age } & $18-25$ & 204 & $55.14 \%$ \\
& $25-35$ & 110 & $29.73 \%$ \\
\hline \multirow{2}{*}{ Education } & $35-45$ & 52 & $14.05 \%$ \\
& $45-60$ & 4 & $1.08 \%$ \\
\hline & High school or technical secondary school & 18 & $4.86 \%$ \\
& Junior College & 63 & $17.03 \%$ \\
\hline & Undergraduate & 260 & $70.27 \%$ \\
Graduate student and above & 29 & $7.84 \%$ \\
\hline & R \& D design department & 81 & $21.89 \%$ \\
\hline & Management personnel & 78 & $21.08 \%$ \\
\hline
\end{tabular}

\subsection{Variable Measure}

The entire questionnaire was scored by Scale Likert 5 scale, and 1 of them was very inconsistent, and 5 indicated that it was very consistent. Psychological contract test items mainly refer to the staff psychological contract scale developed by the Rousseau [25], at the same time, combined with the employee's psychological contract scale developed by $\mathrm{Li}$ in 2006, because the content is more comprehensive, and it is a survey of Chinese enterprise employees, which is consistent with cultural background of the study. Finally, 12 items were formed, 3 of which are transactional psychological contract, 5 are relational psychological contract, and the 4 is the developmental psychological contract.

Based on the Lin [26], the reciprocal preference scale was modified and designed with the definition of Rabin [27]. There are 6 items in this study, including 3 items of reciprocal motivation, 3 of which are reciprocal behavior.

In this paper, knowledge sharing willingness measurement scale was based on the scale by Bock, including 3 items of explicit knowledge sharing willingness, 3 of which are tacit knowledge sharing willingness.

\subsection{Reliability Test and Validity Test}

\subsubsection{Reliability Test}

First of all, according to the data collected by questionnaire survey, have a reliability test for psychological contract, reciprocal preference and knowledge sharing willingness and their dimensions through the software SPSS 19.0 .

Cronbach' $\alpha$ was used to test the reliability of each measure scale, as shown in Table 2.

\subsubsection{Validity Test}

Use KMO and Bartlett's test of sphericity to obtain the value of construct validity. If the KMO value is less than 0.5 , it is not suitable for factor analysis, and now the KMO value was 0.85 , it said that it was suitable for factor analysis, the whole questionnaire validity structure good. Then using confirmatory factor analysis to test the validity of the scale by the software AMOS 22, the results are as shown in Table 3. Obviously, each measure scale has good validity. 
Table 2. Reliability analysis results.

\begin{tabular}{ccc}
\hline Scale name & Cronbach' $\alpha$ & The number of items \\
\hline Total questionnaire & 0.89 & 26 \\
Transactional psychological contract & 0.75 & 3 \\
Relational psychological contract & 0.83 & 5 \\
Developmental psychological contract & 0.85 & 3 \\
Reciprocal motivation & 0.84 & 3 \\
Reciprocal behavior & 0.79 & 4 \\
Explicit knowledge sharing willingness & 0.85 & 4 \\
\hline
\end{tabular}

Table 3. Validity analysis results.

\begin{tabular}{|c|c|c|c|c|c|c|}
\hline Model & $\chi^{2} / \mathrm{df}$ & RMSEA & CFI & NFI & IFI & TLI \\
\hline Psychological contract & 2.80 & 0.07 & 0.95 & 0.93 & 0.95 & 0.94 \\
\hline Reciprocal preference & 2.65 & 0.07 & 0.94 & 0.95 & 0.93 & 0.97 \\
\hline Knowledge sharing willingness & 1.68 & 0.04 & 0.93 & 0.94 & 0.94 & 0.95 \\
\hline Optimal value tendency & $<3$ & $<0.08$ & $>0.9$ & $>0.9$ & $>0.9$ & $>0.9$ \\
\hline
\end{tabular}

\section{Data Analysis}

\subsection{Descriptive Statistical Analysis}

Table 4 shows the mean and standard deviation of each variable and the correlation coefficient between them. Table 4 shows significant positive correlation between relational psychological contract and the knowledge sharing willingness $(\mathrm{p}<0.01)$; developmental psychological contract is positively correlated with the knowledge sharing willingness $(\mathrm{p}<0.01)$; reciprocal preference was positively correlated with the knowledge sharing willingness $(\mathrm{p}<0.01)$. These correlations are consistent with the expected relationship.

\subsection{Research Hypothesis Testing}

As can be seen from Table 5, the transactional psychological contract has a significant negative impact on explicit knowledge and implicit knowledge sharing willingness, which indicates that the employees of transactional psychological contract are not inclined to share knowledge and support the hypothesis H1a, H1b; relational psychological contract has a significant positive impact on explicit knowledge and implicit knowledge sharing willingness, and it shows that the employees of relational psychological contract are more willing to share knowledge with others, supporting the hypothesis H1c, H1d; developmental psychological contract has a significant negative impact on the explicit knowledge sharing willingness, but no significant effect on tacit knowledge sharing willingness, assuming that $\mathrm{H} 1 \mathrm{f}$ and $\mathrm{H} 1 \mathrm{e}$ have not been verified.

In addition, the study also found that transactional psychological contract has a direct impact on the reciprocal preference, which shows that the level of reciprocal preference of employees with transactional psychological contract is low; relational psychological contract has a significant positive effect on reciprocal benefit, and it shows that the employees of the relational psychological contract are more easily to produce reciprocal preference; relational psychological contract has a significant positive effect on reciprocal benefit, and it shows that the employee of the relational psychological contract are more easily to have the reciprocal preference; the developmental psychological contract has no direct effect on the preference of reciprocal benefit. Finally, this study found that the reciprocal motivation can generate the reciprocal behavior, and then will have a significant positive effect on the explicit knowledge and implicit knowledge sharing. All these support the hypothesis H2a, $\mathrm{H} 2 \mathrm{~b}, \mathrm{H} 2 \mathrm{c}$. 
Table 4. Mean standard deviation and correlation coefficient.

\begin{tabular}{|c|c|c|c|c|c|c|c|c|}
\hline Variable & M & $\mathrm{SD}$ & 1 & 2 & 3 & 4 & 5 & 6 \\
\hline 1. Transactional & 3.33 & 0.77 & 1.00 & & & & & \\
\hline 2. Relational & 3.50 & 0.73 & $0.44^{* *}$ & 1.00 & & & & \\
\hline 3. Developmental & 3.71 & 0.82 & $0.37^{* *}$ & $56^{* *}$ & 1.00 & & & \\
\hline 4. Reciprocal motivation & 3.99 & 0.81 & -0.02 & $0.22^{* *}$ & $0.17^{* *}$ & 1.00 & & \\
\hline 5. Reciprocal preference & 3.75 & 0.68 & 0.02 & $0.28^{* *}$ & $0.32^{* *}$ & $0.53^{* *}$ & 1.00 & \\
\hline 6. Explicit knowledge sharing & 3.90 & 0.74 & -0.04 & $0.23^{* *}$ & $0.15^{* *}$ & $0.61^{* *}$ & $0.53^{* *}$ & 1.00 \\
\hline 7. Tacit knowledge sharing & 3.91 & 0.66 & 0.01 & $0.29^{* *}$ & $0.21^{* *}$ & $0.53^{* *}$ & $0.46^{* *}$ & $0.58^{* *}$ \\
\hline
\end{tabular}

Note: ${ }^{* * *} \mathrm{p}<0.001,{ }^{* *} \mathrm{p}<0.01, \stackrel{*}{\mathrm{p}}<0.05$.

Table 5. Path coefficients of the optimal structure model.

\begin{tabular}{clccc}
\hline Path & \multicolumn{1}{c}{ Relationship between variables } & Path coefficient & hypothesis & result \\
\hline 1 & Transactional Explicit knowledge & $-0.21^{* * *}$ & H1a & yes \\
2 & Relational Explicit knowledge & $0.35^{* * *}$ & H1c & yes \\
3 & Developmental Explicit knowledge & $-0.21^{*}$ & H1e & no \\
4 & Transactional Tacit knowledge & $-0.21^{* * *}$ & H1b & yes \\
5 & Relational Tacit knowledge & $0.33^{* * *}$ & H1d & yes \\
6 & Reciprocal motivation Reciprocal behavior & $0.46^{* * *}$ & H2a & yes \\
7 & Reciprocal behavior Explicit knowledge & $0.72^{* * *}$ & H2b & yes \\
8 & Reciprocal behavior Tacit knowledge & $0.40^{* * *}$ & H2c & yes \\
9 & Transactional Reciprocal preference Explicit knowledge & & H3a & yes \\
10 & Transactional Reciprocal preference Tacit knowledge & & H3d & yes \\
11 & Relational Reciprocal preference Explicit knowledge & & H3b & yes \\
12 & Relational Reciprocal preference Tacit knowledge & & H3e & yes \\
\hline
\end{tabular}

Note: ${ }^{*} \mathrm{p}<0.05,{ }^{* *} \mathrm{p}<0.01,{ }^{* * *} \mathrm{p}<0.001$.

Figure 2 further shows the relationship between the variables obtained after the correction of the overall structural model. As can be seen from Figure 2, transactional and relational psychological contract can affect employees' willingness to share knowledge through two ways: one is the direct effect, it is that transactional and relational psychological contract has a direct impact on knowledge sharing; another is through the indirect effect of reciprocal preference, assuming that $\mathrm{H3a}, \mathrm{H} 3 \mathrm{~b}, \mathrm{H} 3 \mathrm{~d}, \mathrm{H} 3 \mathrm{e}$ have been verified. However, developmental psychological contract only has a significant positive effect on explicit knowledge sharing willingness. It is not affected by the reciprocal preference of knowledge sharing willingness, and it is assumed that $\mathrm{H} 3 \mathrm{c}$ is not verified, unable to affect the knowledge sharing willingness through the reciprocal preference, so the H3c is not verified. And the reciprocal preference does not play a mediation role in the relationship between developmental psychological contract tacit knowledge sharing willingness, so the hypothesis H3fis not verified.

\section{Research Conclusions}

This paper verifies that the type of psychological contract has a significant impact on knowledge sharing willingness from the point of empirical way, and the transactional psychological contract has a significant negative impact on knowledge sharing willingness, which is consistent with the result of $\mathrm{He}$ and Li; relational psychological contract has a significant positive effect on the knowledge sharing willingness and the results are consis- 


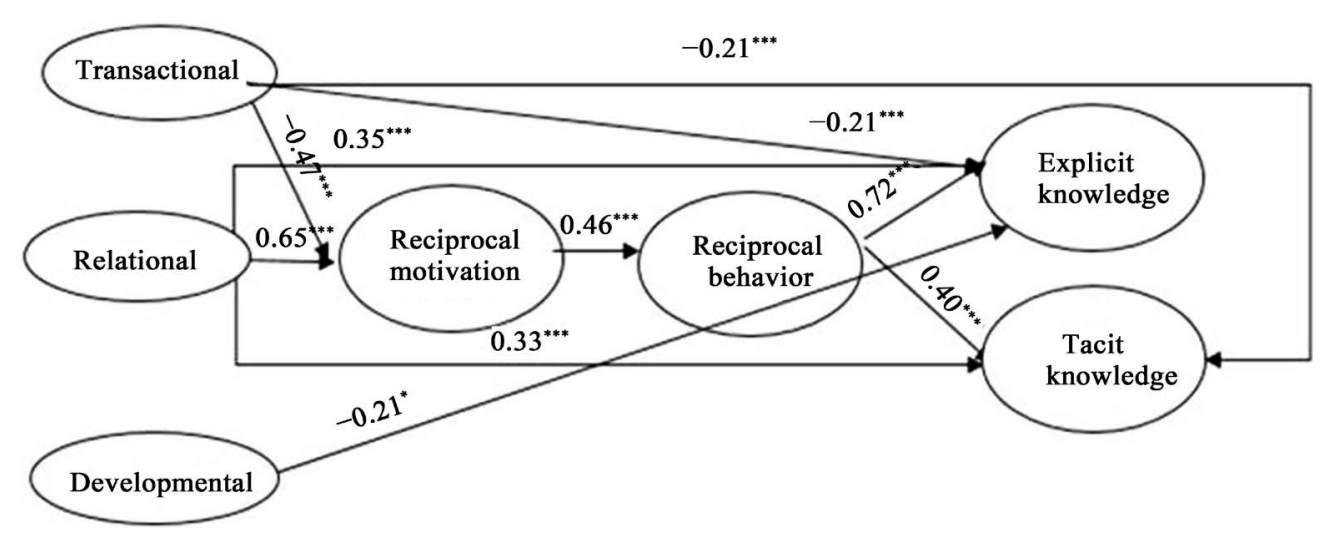

Figure 2. The modified structure model and the relationship between variables.

tent with the results of Liza Abdullah Nor; however the developmental psychological contract has a significant negative effect on explicit knowledge sharing willingness, and has no significant effect on tacit knowledge sharing willingness which is inconsistent with the research hypothesis in this paper.

Reciprocal preference has a significant positive impact on knowledge sharing willingness, which is consistent with the conclusions of G. W. Bock and Lee, N. Jitney found that the reciprocal relationship can affect the attitude of employees' willingness to share knowledge, that is, the stronger the preference is, the more they tend to share their knowledge.

In addition, this study also finds that the reciprocal preference plays a partial mediation role in the relationship between psychological contract and knowledge sharing willingness. On the basis of the above analysis, it is indicated that transactional psychological contract can affect the knowledge sharing willingness through reciprocal preference, and there is a negative correlation between transactional psychological contract and reciprocal preference. That is to say, the employees with transactional psychological contract tend to have lower reciprocal preference, thus reducing their knowledge sharing willingness. Relational psychological contract has a significant positive correlation with reciprocal preference, and the employees with this psychological contract have a high degree of reciprocal motivation and behavior.

\section{References}

[1] Arthur, J.B. and Huntley, C.L. (2005) Ramping up the Organizational Learning Curve: Assessing the Impact of Deliberate Learning on Organizational Performance under Gain Sharing. Academy of Management Journal, 48, 1159-1170. http://dx.doi.org/10.5465/AMJ.2005.19573115

[2] Cohen, W.M. and Levinthal, D.A. (1990) Absorptive Capacity: A New Perspective on Learning and Innovation. Administrative Science Quarterly, 35, 128-152. http://dx.doi.org/10.2307/2393553

[3] Cabrera, A. (2002) Knowledge-Sharing Dilemmas. Organization Studies, 23, 687-710. http://dx.doi.org/10.1177/0170840602235001

[4] Husted, K. and Michailova, S. (2002) Diagnosing and Fighting Knowledge-Sharing Hostility. Organizational Dynamics, 31, 60-73. http://dx.doi.org/10.1016/S0090-2616(02)00072-4

[5] Argyris, C. (2005) Understanding Organizational Behavior. Understanding Organizational Behavior, 26, 457-458.

[6] Kotter, J.P. (1973) The Psychological Contract: Managing the Joining-Up Process. California Management Review, 15, 91-99. http://dx.doi.org/10.2307/41164442

[7] Rousseau, D.M. (1990) New Hire Perceptions of Their Own and Their Employer's Obligations: A Study of Psychological Contracts. Journal of Organizational Behavior, 11, 389-400. http://dx.doi.org/10.1002/job.4030110506

[8] Rousseau, D.M. (1995) Psychological Contracts in Organizations. Annales des Mines - Gérer et comprendre.

[9] Li, Y. and Guo, D.J. (2006) Research on the Structure and Internal Relationship of Employee Psychological Contract. Sociological Research, 5, 151-168.

[10] Rabin, M. (1993) Incorporating Fairness into Game Theory and Economics. American Economic Review, 83, 12811302.

[11] Goranson, R.E. and Berkowitz, L. (1966) Reciprocity and Responsibility Reactions to Prior Help. Journal of Personality \& Social Psychology, 3, 227-232. http://dx.doi.org/10.1037/h0022895 
[12] Sternberg, R.J. (1997) Successful Intelligence. Penguin Putnam, New York.

[13] Kang, M. and Kim, Y. (1999) Development of Knowledge Flow Diagram for Intra-Organizational Knowledge-Sharing Enhancement. In: Ryu, S.C., Eds., Proceedings of the Conference of Korea Society of Management Information System, 141-152.

[14] Dyer, J. and Nobeoka, K. (2000) Creating and Managing a High Performance Knowledge Sharing Network: The Toyota Case. Strategic Management Journal, 21, 345-367. http://dx.doi.org/10.1002/(SICI)1097-0266(200003)21:3<345::AID-SMJ96>3.0.CO;2-N

[15] Storey, J. (2001) Human Resource Management: A Critical Text. 2nd Edition, Thomson Learning, New York.

[16] Husted, K. and Michailova, S. (2002) Diagnosing and Fighting Knowledge-Sharing Hostility. Organizational Dynamics, 31, 60-73. http://dx.doi.org/10.1016/S0090-2616(02)00072-4

[17] Liang, Q.H. and Yu, G.S. (2006) Enterprise Tacit Knowledge Transfer and Sharing Management Based on Psychological Contract. Research and Development Management, 18, 77-85.

[18] He, M.R. and Li, Y.J. (2011) An Empirical Study on the Influence of Psychological Contract Types on the Tacit Knowledge Sharing Willingness. Journal of Management, 8, 56-60.

[19] Lu, F.C. and Chen, X.F. (2012) Knowledge Workers' Psychological Contract, Organizational Trust and Knowledge Sharing Willingness. Economic Management, 34, 76-83.

[20] Kollock, P. (1999) The Economies of Online Cooperation: Gifts and Public Goods in Cyberspace. Communities in Cyberspace, 2010.

[21] Bock, G.W. and Lee, J.N. (2005) Behavioral Intention Formation in Knowledge Sharing: Examining the Roles of Extrinsic Motivators, Social-Psychological Forces, and Organizational Climate. Mis Quarterly, 29, 87-111.

[22] Goh, S.K. and Sandhu, M.S. (2013) Affiliation, Reciprocal Relationships and Peer Pressure in Knowledge Sharing in Public Universities in Malaysia. Asian Social Science, 9, 290. http://dx.doi.org/10.5539/ass.v9n7p290

[23] Zhang, T.J. and Pu, Y.J. (2010) Research on the Relationship between Reciprocal Preference, Tacit Knowledge Transfer and Technological Innovation Ability-Based on the Data Test of R \& D Team. Management Review, 22, 100-106.

[24] Bal, M., De Cooman, R. and Mol, S. (2010) Reciprocal Relations between Psychological Contracts and Work Outcomes. Academy of Management Meeting, Montreal.

[25] Rousseau, D.M. and Tijoriwala (1996) Perceived Legitimacy \& Unilateral Contract Changes: It Takes a Good Reason to Change Psychological Contract. Symposium at the SIOP Meetings, Sna Diago, 1996.

[26] Lin, H.F. (2007) Effects of Extrinsic and Intrinsic Motivation on Employee Knowledge Sharing Intentions. Journal of Information Science, 33, 135-149. http://dx.doi.org/10.1177/0165551506068174

[27] Rabin, M. (2000) Psychology and Economics. Department of Economics Working Paper, 36, 11-46.

\section{Submit or recommend next manuscript to SCIRP and we will provide best service for you:}

Accepting pre-submission inquiries through Email, Facebook, LinkedIn, Twitter, etc.

A wide selection of journals (inclusive of 9 subjects, more than 200 journals)

Providing 24-hour high-quality service

User-friendly online submission system

Fair and swift peer-review system

Efficient typesetting and proofreading procedure

Display of the result of downloads and visits, as well as the number of cited articles

Maximum dissemination of your research work

Submit your manuscript at: http://papersubmission.scirp.org/ 